\title{
Comparison of Lung Functions Before and After Sports in Normal and Obese Students at Warmadewa University
}

\author{
K T Sumadewi ${ }^{1 *}$, I G N B Pramana ${ }^{1}$, I G N P Sana ${ }^{1}$ \\ ${ }^{1}$ Faculty of Medicine and Health Sciences, Universitas Warmadewa, Denpasar, Bali \\ *drtriscel@gmail.com
}

\begin{abstract}
Obesity is one of the leading causes of health problems. Many studies have shown significant associations between obesity and lung disorders in the form of obstructive sleep apnea (OSA) and asthma, but it remains to be debated whether there is an obstructive or restrictive disorder in obese people. The purpose of this study was to determine the ratio of lung function before and after exercise in the normal and obesity group of medical students. The research design used was quasi experimental with pretest and posttest design, using Pearson Chi- Square hypothesis test, Wilcoxon Sign Rank Test, and Mann Whitney U Test. There were 60 samples (30 men and 30 women) divided into normal and obese with an average age of 19.47. The result shows that in the normal group, the average of delta value of FEV1 equal to 0.13 , FVC equal to 0.10 , and lung function equal to 0.87 . While in the obese group, the mean value of delta FEV1 is $0.17, \mathrm{FVC}$ of 0.00 , and lung function of -4.92 . The conclusion of this study is the change of lung function between normal and obese group show significant differencesnamely an increase in the normal group and a decline in the obese group.
\end{abstract}

Keyword : Comparison, Sport, Warmadewa University.

\section{Introduction}

Obesity is a condition in which a person has excessive fat accumulation with body mass index (BMI) of more than or equal to 30 [1]. Excessive fat accumulation can be caused by excessive nutrient intake accompanied by lack of physical activity or due to genetic influences [2]. In the period from 2010 to 2013, there was a sharp increase in the prevalence of obesity in Indonesia. The prevalence of obese adult males population in 2013 was $19.7 \%$, compared to only $7.8 \%$ in 2010 . Meanwhile, the prevalence of adult females with obesity in 2013 was $32.9 \%$, more than twice than that of in 2010 (15.5\%). In 2013, the highest prevalence of obese adults in Indonesia is occupied by North Sulawesi (24\%), while Bali was included in 16 provinces with the prevalence of obesity was above the National average of $15.5 \%$ [3]. In Bali Province specifically, Denpasar City ranked first with the prevalence of $17.6 \%$ [4].

Obese people have a high risk of suffering from various diseases such as diabetes mellitus, hypertension, dyslipidemia, metabolic syndrome, osteoarthritis, cancer, heart, cerebrovascular, gastrointestinal, reproductive, psychosocial, and pulmonary disease [5]. Many studies have shown a significant association between obesity and pulmonary disorders such as obstructive sleep apnea (OSA) and asthma. The mechanism of the occurrence of the disorder is thought to be due to the accumulation of fatty tissue in the respiratory tract, which increases the likelihood of bronchoconstriction [6]. However, there are other studies that suggest that obese people have restrictive lung disorders $[7,8]$. 
The most common obstructive disorder found in obese people is OSA. OSA is the collapse of the pharynx during sleep, resulting in intermittent hypoxia, daytime drowsiness, and increasing the risk of cardiovascular diseases [9]. This is caused by the accumulation of fatty tissue in the respiratory tract, especially in the pharynx, and thus increase the possibility of collapse [6]. In addition, in individual with asthma, obesity will increase the frequency of recurrence and aggravate the disease [10]. In obesity, restrictive abnormalities may occur due to accumulation of fat in the thorax, which aggravates the work of the respiratory muscles to expand the chest cavity. These events occur more severely during the sleep position, because the fat mass presses towards the thoracic cavity due to the gravity of the earth, and thus the breathing muscles will get exhausted faster [8]. In addition, a reduction in lung capacity is also caused by decreased ability to expand by the diaphragm caused by fat accumulation in abdominal cavity [7].

Respiratory workload in obese people is estimated to be $60 \%$ greater than normal people, which occurs because of the increased energy that is used to develop thoracic cavities and diaphragms. In normal people, exercise can aggravate the exercise induced bronchospasm (EIB), which is a narrowing of the airways for a few minutes after exercising and causes a decrease in FEV1. EIB can be more severe in obese people. EIB can occur after intense physical exercise for 10 to 15 minutes and will disappear a few minutes after stopping exercise [11].

This study was aimed to compare the lung function before and after exercise in normal and obese people by measuring the ratio of forced expiratory volume in one second divided by forced vital capacity (FEV1/FVC). The FEV1/FVC ratio was used to distinguish and measure the level of obstructive and restrictive pulmonary function abnormalities [12].

\section{Method}

This research was conducted at the Biomedical Laboratory of the Faculty of Medicine and Health Sciences, Warmadewa University, on December 8-16, 2017, at 12.00-15.00 local time. This study used a quasi-experimental design with a pretest and posttest design to compare pulmonary function before and after exercise in normal and obese people. The target population of this study was all students of Warmadewa University, while the accessible population was students of semester I, III, V, and VII at Warmadewa University in 2017. Samples were selected by non-random sampling (quota) from an accessible population. The number of samples used was 30 people in each group. The inclusion criteria of this study were first, third, fifth, and seventh semester students with obese or normal BMI. Students who were athletes, have suffered from respiratory diseases such as shortness of breath, asthma, and OSA, or suffered from respiratory problems such as cough or flu, and have smoking habits were not included in the study [13].

The independent variables in this study were normal BMI and obesity. Meanwhile, the dependent variables were FEV1, FVC, and FEV1/FVC ratios.and the intervention variable was sport. The sport used in this study was stepping up and down the bar using the Harvard step test instrument for 10 minutes. The step bench sizes used were $33 \mathrm{~cm}$ for women and 40 $\mathrm{cm}$ for men. Subjects were taught how to do spirometry tests and exercise using the Harvard step test instrument. Before doing the exercise, samples were tested on spirometry. The subject did stretching, then worked out for 10 minutes. The subjects repeated the spirometry test after resting for 1 minute. Characteristics of the samples were analyzed using Pearson Chi- 
Square and Mann Whitney U Test to compare the lung function innormal and obese groups before and after exercise, and the Wilcoxon Sign Rank Test to compare lung function between before and after exercise in the normal and obese groups.

\section{Results And Discussion}

Table 1 shows the number of samples in this study, an amount of 60 people consisting of 30 people in the group with normal BMI and 30 people with BMI of obesity. The semester distribution in the subject of this study have no significant difference between the normal and obese groups.

Table 1. Characteristics of the Sample

\begin{tabular}{llccc}
\hline Gender & Male & $\begin{array}{c}\text { Normal N=30 } \\
\text { Frequency }\end{array}$ & $\begin{array}{c}\text { Obese } \mathbf{N}=\mathbf{3 0} \\
\text { Frequency }\end{array}$ & $\boldsymbol{p}$ \\
& Female & 15 & 15 & 1,000 \\
\hline \multirow{3}{*}{ Semester } & I & 15 & 15 & 0,946 \\
& III & 10 & 8 & \\
& V & 7 & 7 & \\
& VII & 5 & 6 & \\
\hline
\end{tabular}

Table 2 shows that there were no significant differences in the two groups in terms of age and height. However, there were significant differences in weight and BMI variables.

Table 2. Comparison of Sample Characteristics

\begin{tabular}{llll}
\hline & \multicolumn{1}{c}{ Normal N=30 } & \multicolumn{1}{c}{ Obese $\mathbf{N}=\mathbf{3 0}$} & \multirow{2}{*}{$\boldsymbol{P}$} \\
\cline { 2 - 3 } & \multicolumn{1}{c}{ Mean \pm SD } & Mean \pm SD & \\
\hline Age (years) & $19 \pm 1,43$ & $19,67 \pm 1,40$ & 0,551 \\
Body weight $(\mathrm{kg})$ & $63,93 \pm 6,00$ & $90,19 \pm 10,58$ & 0,000 \\
Height (m) & $1,68 \pm 0,07$ & $1,67 \pm 0,08$ & 0,745 \\
BMI & $22,67 \pm 1,35$ & $32,16 \pm 2,04$ & 0,000 \\
\hline
\end{tabular}

Table 3 shows that before exercise, the average value of FEV1 in the normal group was $3.03 \mathrm{~L} / \mathrm{s}$, whereas in the obese group was $3.50 \mathrm{~L} / \mathrm{s}$, the mean difference had a significance value of 0.001 . The average FVC value in the normal group was $3.14 \mathrm{~L}$, while in the obese group it was $3.79 \mathrm{~L}$, with a significance value of 0.000 . The mean lung function values in the normal group were $96.79 \%$, while in the obese group $93.25 \%$, with a significance of 0.000 .

Table 3. Comparison of Lung Function in the Normal and Obesity Group Before Sports

\begin{tabular}{llll}
\hline & \multicolumn{1}{c}{ Normal $\mathbf{N}=\mathbf{3 0}$} & \multicolumn{1}{c}{ Obese $\mathbf{N}=\mathbf{3 0}$} & \multirow{2}{*}{$\boldsymbol{P}$} \\
\cline { 2 - 3 } & \multicolumn{1}{c}{ Mean \pm SD } & Mean \pm SD & \\
\hline FEV1 $(\mathrm{L} / \mathrm{s})$ & $3,03 \pm 0,55$ & $3,50 \pm 0,59$ & 0,001 \\
FVC $(\mathrm{L})$ & $3,14 \pm 0,62$ & $3,79 \pm 0,71$ & 0,000 \\
Lung function $(\%)$ & $96,79 \pm 3,13$ & $93,25 \pm 9,01$ & 0,000 \\
\hline
\end{tabular}


Table 4 shows that after exercise the average value of FEV1 in the normal group was 3.16 $\mathrm{L} / \mathrm{s}$, while in the obese group it was $3.33 \mathrm{~L} / \mathrm{s}$, with a significance of 0.062 . The average FVC value in the normal group was $3.24 \mathrm{~L}$, while in the obese group it was $3.79 \mathrm{~L}$, with a significance value of 0.002 . The mean lung function values in the normal group were $97.66 \%$, while in the obese group $88.33 \%$, the difference in values had a significance of 0,000 .

Table 4. Comparison of Lung Function in the Normal and Obesity Group After Sports

\begin{tabular}{llll}
\hline & \multicolumn{1}{c}{ Normal N=30 } & \multicolumn{1}{c}{ Obese N=30 } & \multirow{2}{*}{$\boldsymbol{P}$} \\
\cline { 2 - 3 } & \multicolumn{1}{c}{ Mean \pm SD } & \multicolumn{1}{c}{ Mean \pm SD } & \\
\hline FEV1 (L/s) & $3,16 \pm 0,79$ & $3,33 \pm 0,63$ & 0,062 \\
FVC (L) & $3,24 \pm 0,81$ & $3,79 \pm 0,72$ & 0,002 \\
Lung function (\%) & $97,66 \pm 2,53$ & $88,33 \pm 7,17$ & 0,000 \\
\hline
\end{tabular}

The results shown in the table 5 are the average delta values of the normal group at FEV1 of 0.13 , FVC of 0.10 , and lung function of 0.87 . Whereas in the obese group the average delta FEV1 value of -0.17, FVC of 0.00 , and lung function of -4.92 . The difference in the value of delta between the normal and obese groups at the value of FEV1 had a significance of 0.000 , while the FVC value was 0.104 , and the pulmonary function value of 0.000 .

Table 5. Delta Values Between Normal and Obesity Group

\begin{tabular}{llll}
\hline & \multicolumn{1}{c}{ Normal $\mathbf{N}=\mathbf{3 0}$} & \multicolumn{1}{c}{ Obese $\mathbf{N}=\mathbf{3 0}$} & \multirow{2}{*}{$\boldsymbol{P}$} \\
\cline { 2 - 3 } & \multicolumn{1}{c}{ Mean \pm SD } & \multicolumn{1}{c}{ Mean \pm SD } & \\
\hline FEV1 (L/s) & $0,13 \pm 0,46$ & $-0,17 \pm 0,34$ & 0,000 \\
FVC (L) & $0,10 \pm 0,37$ & $0,00 \pm 0,02$ & 0,104 \\
Lung function $(\%)$ & $0,87 \pm 2,55$ & $-4,92 \pm 9,41$ & 0,000 \\
\hline
\end{tabular}

Before exercise, the average FEV1 value in the normal group was smaller than in the obese group and statistically showed a significant difference. The mean FVC value in the normal group was also smaller than the obese group and was statistically significant. However, after calculating the FEV1/FVC ratio (pulmonary function), the mean value in the normal group was significantly greater than the obese group. This was because the lung capacity in the obese group was greater than the normal group [14]. However, the amount of lung capacity was not proportional to the amount of air that can be released within one second and resulting in a smaller FEV1/FVC ratio than the normal group. This result is also in accordance with the research conducted by Devershetty et al. (2015), which shows a reduction in the FEV1/FVC ratio in obese women [15].

After exercise, the average value of FEV1 in the normal group was still lower than in the obese group, but the difference was insignificant due to an increase in value compared to preexercise in the normal group, while in the obese group had decreased. The mean value of FVC in the normal group was still smaller compared to the obese group and had a statistically significant difference, so that the average value of lung function in the normal group remained greater compared to the obese group. This result is different from the results of a study by Moradi \& Sepehri (2014), which mentions that after exercise for 5 minutes, the lung functions of both normal and obese groups show a decrease in value [16]. However, the normal group was still better than the obese group, this was thought the difference in the length of time exercise is done. 
Comparison of the lung function before and after exercise in the normal group shows an increase in the mean value of FEV1. The average FVC value also had a slight increase, resulting in an increase in the mean value of the function. These data indicate that during exercise, adjustments of the physiology of pulmonary function present by increasing lung development ability and increasing the ability to release air per second. This is needed to overcome the increased oxygen demand when exercising. These results are consistent with the research conducted by Tipton et al. (2017) which states that while exercising, the body temperature will increase and cause bronchodilators and increase air flow [17].

In the obese group there was a decrease in the average value of FEV1. This result is in accordance with the research conducted by Moradi \& Sepehri (2014) who found a significant decrease in FEV1 in the obese group after only 5 minutes of exercise. The average value of FVC did not increase, resulting in a decrease in the mean value of lung function. From these data indicate that in the obesity group there was no adjustment in the physiology of lung function.

The delta values between the normal and obese groups showed significant differences in FEV1 values and pulmonary function, whereas the FVC values did not show a significant difference. This indicates that Exercise Induced Bronchospasm (EIB) has occurred in the obese group which causes narrowing of the respiratory tract resulting in shortness of breath and fatigue because of the inability to fulfill the increased oxygen needs while exercising [11]. Other studies suggest that bronchial narrowing occurs in obese is due to the occurrence of hypersensitivity reactions in the bronchi so that often associated with an increased incidence of asthma [18].

\section{Conclusions}

To sum up, the FEV1 values of the normal group is lower than the obese groupfor both before and after exercise. Comparison of FVC shows that the normal group is lower than in the obese group both before and after exercise. Comparison of lung function showed an increase after exercise in the normal group, but a decrease in the obese group. Hence regular physical activity cause many desirable physiological and physical change in the individual.

\section{References}

[1] WHO. WHO|Obesity and overweight, Factsheet No. 311. WHO. 2015. http://www.who.int/mediacentre/factsheets/fs311/en/\%5Cnhttp://who.int/mediacentre/factsheet s/fs311/en/.

[2] Ayu R, Sartika D. Faktor Risiko Obesitas Pada Anak 5-15 Tahun Di Indonesia, 2011. 15(1): p.37-43.

[3] Badan Penelitian Dan Pengembangan Kesehatan Kementerian Kesehatan RI. Riset Kesehatan Dasar. Minist Heal Repub Indones. 2013;(1):1-303. doi:10.1007/s13398-014-0173-7.2.

[4] Riskesdas Bali. Riskesdas dalam Angka Provinsi Bali Tahun 2013.; 2013. doi:10.1017/CBO9781107415324.004.

[5] Ali AT, Crowther NJ. Health risks associated with obesity. JEMDSA, 2015.10.

[6] Eckert DJ, Malhotra A. Pathophysiology of adult obstructive sleep apnea. Proc Am Thorac Soc, 2008. 5(2): p.144-153. doi:10.1513/pats.200707-114MG 
[7] Mahajan S, Arora AK, Gupta P. Correlation of Obesity and Pulmonary Functions in. Pak J Physio, 2012. 8(2): p.6-9.

[8] Sudhir GK, Chandrashekara P. Correlation of Body Mass Index and Pattern of Pulmonary Function among South Indian Adult Males, 2014. 10(3): p.447-450.

[9] Bonsignore MR, McNicholas WT, Montserrat JM, Eckel J. Adipose Tissue in Obesity and Obstructive Sleep Apnoea. Eur Respir J, 2012. 39(3): p.746-767. doi:10.1183/09031936.00047010.

[10] Malnick SDH, Knobler H. The Medical Complications Of Obesity. Qjm, 2006. 99(9): p.565579. doi:10.1093/qjmed/hcl085.

[11] Molis MA, Molis WE. Exercise- induced bronchospasm. Sports Health, 2010. 2(4): p. 311317. doi:10.1177/1941738110373735.

[12] Pellegrino R, Viegi G, Brusasco V, et al. Interpretative strategies for lung function tests. Eur Respir , 2005. 26(5): p. 948-968. doi:10.1183/09031936.05.00035205

[13] Cooper BG, Cooper BG. An Update On Contraindications For Lung Function Testing, 2011. doi:10.1136/thx.2010.139881.

[14] Ristianingrum I, Rahmawati I, Rujito L. Hubungan Antara Indeks Massa Tubuh (Imt) Dengan Tes Fungsi Paru, 2010. 4:105-112.

[15] Devershetty J, Metta S, Uppala S, Kamble G. Effect Of Obesity On Pulmonary Function Tests In Apparently Healthy Young Women, 2015. 4(11): p.1519-1522. doi:10.5455/ijmsph.2015.28042015313.

[16] Moradi M, Sepehri MH. The Effects Of Obesity On Spirometric Variables Following A SubMaximal Exercise Challenge Pelagia Research Library, 2014. i(4): p.141-146.

[17] Tipton MJ, Kadinopoulos P, Sa DR De, Barwood MJ. Changes In Lung Function During Exercise Are Independently Mediated By Increases In Deep Body Temperature, 2017: p. 1-8. doi:10.1136/bmjsem-2016-000210.

[18] Salome CM, King GG, Berend N. Physiology Of Obesity And Effects On Lung Function, 2018: p. 206-211. doi:10.1152/japplphysiol.00694.2009. 